\title{
Evaluasi Kepatuhan Pelaksanaan Standar Prosedur Operasional Manajemen Nyeri pada Pasien Luka Bakar di RSUP Dr. Hasan Sadikin Bandung
}

\author{
Yudhanarko, ${ }^{1}$ Suwarman, ${ }^{2}$ Ricky Aditya ${ }^{2}$ \\ ${ }^{1}$ Bagian Anestesi Rumah Sakit PMI Bogor, ${ }^{2}$ Departemen Anestesiologi dan Terapi Intensif \\ Fakultas Kedokteran Universitas Padjadjaran/RSUP Dr. Hasan Sadikin Bandung
}

\begin{abstract}
Abstrak
Nyeri didefinisikan sebagai pengalaman sensorik dan emosional yang tidak menyenangkan terkait dengan kerusakan jaringan aktual atau potensial. Manajemen nyeri pada luka bakar merupakan bagian yang tidak terpisahkan dari terapi luka bakar. Nyeri pada luka bakar merupakan nyeri akut, penanganan yang tidak baik akan menyebabkan komplikasi, salah satunya nyeri kronik. Rumah Sakit Umum Pusat (RSUP) Dr. Hasan Sadikin Bandung telah membuat standar prosedur operasional (SPO) manajemen nyeri yang berguna untuk meningkatkan kepatuhan dalam pelaksanaan manajemen nyeri. Penelitian ini bertujuan mengevaluasi kesesuaian teknik pengkajian, tindak lanjut dan evaluasi ulang nyeri pada pasien luka bakar dengan SPO manajemen nyeri. Penelitian menggunakan metode deskriptif observasional retrospektif terhadap 99 rekam medis pasien luka bakar yang memenuhi kriteria inklusi di RSUP Dr. Hasan Sadikin Bandung pada tahun 2018. Hasil penelitian didapatkankan bahwa pengkajian nyeri yang dilakukan sesuai dengan SPO menggunakan numeric rating scale atau Wong Baker faces pain scale ditemukan pada 99 pasien (100\%). Tindak lanjut hasil pengkajian nyeri luka bakar yang dilakukan sesuai dengan SPO sebanyak 71 pasien (72\%). Evaluasi ulang setelah tindak lanjut pengkajian nyeri yang sesuai SPO pada 93 pasien (94\%). Simpulan, pengkajian nyeri di RSUP Dr. Hasan Sadikin Bandung sudah sesuai dengan SPO manajemen nyeri, namun tindak lanjut dan evaluasi ulang pada nyeri luka bakar belum sesuai dengan SPO manajemen nyeri.
\end{abstract}

Kata kunci: Luka bakar, manajemen nyeri, nyeri, standar prosedur operasional

\section{Evaluation of Compliance to Standard Operating Procedures for Pain Management in Patients with Burns in Dr. Hasan Sadikin General Hospital Bandung}

\begin{abstract}
Pain is defined as an unpleasant sensory and emotional experience related to actual or potential tissue damage. Pain management for burns is an integral part of burn therapy. Pain in burns is an acute pain and poor management will lead to health complications including chronic pain. Dr. Hasan Sadikin General Hospital Bandung has made a standard operating procedure (SOP) for pain management to improve compliance to pain management standard. This study aimed to evaluate the compliance to the standards in assessment techniques, follow-up, and re-evaluation of pain in patients with burn according to the applicable pain management SOP. This was a retrospective descriptive observational study on 99 medical records of burn patients who met the inclusion criteria in Dr. Hasan Sadikin General Hospital Bandung in 2018. The results of the study revealed that the pain assessment for these patient was carried out according to the SOP which refers to the use of a numeric rating scale or Wong Baker face pain scale in 99 patients $(100 \%)$. In the follow-up, 71 were performed according to the SOP (72\%) while the re-evaluation was performed in compliance with the SOP in 93 patients (94\%). In conclusion, pain assessment in Dr. Hasan Sadikin General Hospital Bandung is performed in accordance with SOP on pain management but not all patients receive follow-up and re-evaluation of burn pain in accordance with the SOP on pain management.
\end{abstract}

Key words: Burns, pain management, pain, standard operating procedures

Korespondensi: Yudhanarko, dr, Bagian Anestesi Rumah Sakit PMI Bogor, Jl. Pajajaran No. 80 Bogor, Tlpn 02518324080,Email yudha_gudoctor@yahoo.com 


\section{Pendahuluan}

Luka bakar merupakan salah satu masalah kesehatan dunia yang menyebabkan sekitar 180.000 kematian setiap tahunnya. Sebagian besar kasus luka bakar terjadi di negaranegara berpenghasilan rendah dan menengah dan hampir dua pertiganya terjadi di negaranegara Afrika dan Asia Tenggara. Hal tersebut berhubungan dengan kurang pengawasan, kewaspadaan, maupun pendidikan tentang keselamatan dasar pencegahan risiko cedera luka bakar di wilayah tersebut. Luka bakar dapat mengakibatkan morbiditas ataupun mortalitas yang tinggi, gangguan psikologis, dan gangguan kualitas hidup yang dialami penderita. Luka bakar sering membutuhkan perawatan jangka panjang dan beberapa prosedur bedah rekonstruktif di rumah sakit. Seiring peningkatan perkembangan sosial ekonomi dunia, banyak penelitian dilakukan untuk mengurangi tingkat morbiditas maupun mortalitas akibat luka bakar. Sebuah studi serupa tentang perkembangan manajemen luka bakar telah dilakukan, tetapi hanya mengevaluasi populasi Eropa. 1,2 $^{2}$

Manajemen nyeri untuk luka bakar merupakan bagian yang tidak terpisahkan dari manajemen luka bakar yang berhubungan dengan proses penyembuhan luka bakar itu sendiri. Penelitian manajemen nyeri pernah dilakukan di RSUP Dr. Hasan Sadikin tahun 2017, menggambarkan efektivitas pemberian analgetik pada nyeri akut selama tahun 2017 didapatkan angka sebesar 70,3\%. Hasil tersebut masih belum memenuhi target bebas nyeri $100 \%$. Nyeri pada luka bakar merupakan nyeri akut. Nyeri akut yang tidak teratasi dapat menyebabkan beberapa akibat, yaitu respons nyeri yang tidak hilang atau berkurang, meningkatkan risiko nyeri kronik, mampu meningkatkan respons inflamasi tambahan, mengganggu proses penyembuhan luka, meningkatkan waktu perawatan di rumah sakit yang akan berakibat lanjut peningkatan risiko infeksi nasokomial, bahkan dapat meningkatkan kejadian mortalitas. ${ }^{3-5}$ Penelitian di Rumah Sakit Umum Pusat Cipto Mangunkusumo Jakarta tahun 2011 sampai dengan 2012 menggambarkan angka mortalitas pada pasien luka bakar masih cukup tinggi, yaitu sebesar $27,6 \%$. Salah satu upaya menurunkan angka mortalitas yang tinggi tersebut adalah diterapkan manajemen nyeri yang baik. ${ }^{6,7}$

Nyeri didefinisikan sebagai pengalaman sensorik dan juga emosional yang tidak menyenangkan terkait dengan kerusakan jaringan aktual atau potensial. Nyeri bersifat individual yang dipengaruhi oleh genetik, budaya, usia dan jenis kelamin sehingga respons nyeri sangat bervariasi antarindividu. ${ }^{8}$ Luka bakar adalah luka yang ditimbulkan akibat paparan air panas, api, cairan kimia pada tubuh sehingga menyebabkan kerusakan pada kulit maupun jaringan di bawahnya. Selain itu, luka bakar pun dapat terjadi akibat dari trauma listrik dengan efek yang dapat bersifat akut ataupun kronik dengan morbiditas yang lebih tinggi. ${ }^{9,10}$

Rumah Sakit Umum Pusat (RSUP) Dr. Hasan Sadikin Bandung telah membuat standar prosedur operasional (SPO) berdasar keputusan direktur utama RSUP Dr. Hasan Sadikin Bandung dengan nomor HK.02. 03/X.4.1.3/6992/2018 tentang panduan manajemen nyeri di Rumah Sakit Umum Pusat Dr. Hasan Sadikin Bandung. Pengkajian nyeri merupakan bagian penting dalam manajemen nyeri yang menentukan pemberian terapi yang sesuai sehingga pasien terbebas dari rasa nyeri. Manajemen nyeri yang baik menghasilkan pemulihan luka bakar yang lebih baik pula. Dalam penanganan nyeri pada luka bakar, tindak lanjut hasil pengkajian tersebut dan evaluasi ulang sangat berpengaruh terhadap keberhasilan penanganan nyeri. ${ }^{11-13}$

Sampai saat ini belum ada penelitian tentang evaluasi kepatuhan pelaksanaan SPO manajemen nyeri pada pasien luka bakar di RSUP Dr. Hasan Sadikin, ditinjau dari pengkajian nyeri, tindak lanjut, dan evaluasi ulang yang dilakukan. Tujuan penelitian ini adalah memberikan data ilmiah kepatuhan pelaksanaan SPO manajemen nyeri yang diberikan pada pasien luka bakar di RSUP Dr. Hasan Sadikin pada tahun 2018. Hasil penelitian ini diharapkan dapat menjadi 
perhatian dalam proses terapi luka bakar sebagai bagian yang tidak terpisahkan dari terapi luka bakar itu sendiri.

\section{Subjek dan Metode}

Penelitian ini merupakan penelitian deskriptif observasional. Objek penelitian adalah rekam medis pasien dengan luka bakar di RSUP Dr. Hasan Sadikin Bandung. Kriteria inklusi pada penelitian ini adalah rekam medis pasien dewasa dengan luka bakar di RSUP Dr. Hasan Sadikin Bandung pada tahun 2018, baik operasi maupun tanpa operasi. Kriteria eksklusi meliputi rekam medis pasien luka bakar yang dirawat di ruang intensive care unit. Kriteria pengeluaran bila lembar pengkajian nyeri di dalam rekam medis rusak atau tulisan tidak terbaca. Peneliti melakukan pencatatan data rekam medis setelah mendapatkan persetujuan dari Komite Etik Penelitian Kesehatan Fakultas Kedokteran Universitas Padjadjaran/ RSUP Dr. Hasan Sadikin Bandung No: LB.02.01/X.6.5/36/2019. Data penelitian yang diambil adalah usia, jenis kelamin, luas luka bakar, tingkat pendidikan, pengkajian nyeri, tindak lanjut (terapi), dan evaluasi ulang nyeri. Pengkajian nyeri sesuai dengan SPO di RSUP Dr. Hasan Sadikin berdasar waktu dan teknik. Waktu dikaji segera saat pasien tiba di ruang pemeriksaaan.

Teknik pengkajian dengan skala numeric rating scales untuk dewasa dan wong baker faces pain scale untuk pasien yang tidak dapat berkomunikasi atau anak. Tindak lanjut sesuai SPO dengan terapi farmakologi. Terapi farmakologi untuk nyeri ringan adalah dengan pemberian parasetamol atau non steroidal anti inflammatory drugs (NSAID), untuk nyeri sedang dengan kombiasi opioid lemah dan parasetamol/NSAID, serta untuk nyeri berat dengan kombinasi opioid kuat dan parasetamol/NSAID. Evaluasi ulang dilakukan tiap 8 jam pada nyeri ringan, 2 jam pada nyeri sedang, dan 1 jam pada nyeri berat. Data hasil penelitian dianalisis kemudian dideskripsikan mempergunakan persentase sesuai dengan variabel yang diidentifikasi selama penelitian. ${ }^{13}$
Tabel 1 Karakteristik Umum Pasien

\begin{tabular}{lc}
\hline \multicolumn{1}{c}{ Variabel } & n (\%) \\
\hline Usia (tahun) & \\
Mean \pm Std & $43,70 \pm 14,619$ \\
$18-40$ & $37(37 \%)$ \\
$41-60$ & $47(48 \%)$ \\
$>60$ & $15(15 \%)$ \\
Jenis kelamin & \\
Laki-laki & $69(70 \%)$ \\
Perempuan & $30(30 \%)$ \\
Luas luka bakar (\%) & \\
$\leq 10$ & $46(47 \%)$ \\
$11-20$ & $30(30 \%)$ \\
$21-30$ & $9(9 \%)$ \\
$31-40$ & $8(8 \%)$ \\
$41-50$ & $0(0 \%)$ \\
$>50$ & $6(6 \%)$ \\
Tingkat pendidikan & \\
SD & $3(3 \%)$ \\
SLTP & $1(1 \%)$ \\
SLTA & $74(75 \%)$ \\
D3 & $11(11 \%)$ \\
S1 & $10(10 \%)$ \\
\hline
\end{tabular}

Keterangan: data kategorik disajikan dengan jumlah atau frekuensi dan persentase, sedangkan data numerik disajikan dengan mean, median, st. deviasi, dan range (min.-maks.)

\section{Hasil}

Jumlah rekam medis pasien luka bakar yang diteliti pada penelitian ini sebanyak 99 rekam medis. Sebagian besar pasien berjenis kelamin laki-laki sebanyak 69 pasien $(70 \%)$.

Tabel 2 Pengkajian Nyeri Luka Bakar dan Tindak Lanjut Pengkajian Nyeri Luka Bakar berdasar Kesesuaian SPO

\begin{tabular}{lc}
\hline \multicolumn{1}{c}{ Variabel } & Jumlah n (\%) \\
\hline Pengkajian nyeri luka bakar & \\
Sesuai SPO & $99(100 \%)$ \\
Tidak sesuai SPO & $0(0 \%)$ \\
Tindak lanjut pengkajian nyeri & \\
luka bakar & \\
Sesuai SPO & $71(72 \%)$ \\
Tidak sesuai SPO & $28(28 \%)$ \\
\hline
\end{tabular}

Keterangan: data kategorik, data disajikan dengan jumlah atau frekuensi dan persentase 
Tabel 3 Analgesik yang Diberikan pada Pasien Luka Bakar

\begin{tabular}{lccc}
\hline $\begin{array}{c}\text { Skala Nyeri } \\
\text { Pasien }\end{array}$ & $\begin{array}{c}\text { Parasetamol/NSAID } \\
\text { n (\%) }\end{array}$ & $\begin{array}{c}\text { Parasetamol/NSAID + } \\
\text { Opioid Lemah } \\
\text { n (\%) }\end{array}$ & $\begin{array}{c}\text { Parasetamol/NSAID+ } \\
\text { Opioid Kuat } \\
\text { n (\%) }\end{array}$ \\
\hline Nyeri ringan & $43(100 \%)$ & $0(0 \%)$ & $0(0 \%)$ \\
Nyeri sedang & $19(40 \%)$ & $27(56 \%)$ & $2(4 \%)$ \\
Nyeri berat & $3(38 \%)$ & $4(50 \%)$ & $1(12 \%)$ \\
\hline
\end{tabular}

Keterangan: data kategorik disajikan dengan jumlah atau frekuensi dan persentase, sedangkan data numerik disajikan dengan mean, median, standar deviasi, dan range (min.-maks.)

Usia rerata pasien adalah $43,70 \pm 14,62$ tahun. Luas luka bakar terbanyak adalah $\leq 10 \%$ total body surface area (47\%) dan kedua terbanyak, yaitu $11-20 \%$ total body surface area (30\%). Latar belakang pendidikan terbanyak adalah Sekolah Lanjutan Tingkat Atas (SLTA), yaitu 75\% (Tabel 1).

Nyeri luka bakar yang dikaji sesuai SPO dengan Numeric rating scale (NRS) untuk pasien dewasa atau dengan Wong Baker faces pain scale untuk dewasa yang tidak dapat berkomunikasi ditemukan pada 99 (100\%). Tindak lanjut hasil pengkajian nyeri luka bakar yang sesuai SPO ditemukan sebanyak 71 pasien atau sebesar 71,7\% (Tabel 2).

Nyeri ringan yang diberikan terapi sesuai SPO manajemen nyeri (parasetamol atau NSAID) didapatkan sebesar 43 pasien (100\%). Untuk nyeri sedang yang diberikan terapi yang sesuai dengan SPO (parasetamol/NSAID + opioid lemah) sebesar 27 pasien (56\%). Nyeri berat yang diberikan terapi sesuai SPO (parasetamol/NSAID + opioid kuat) sebesar 1 pasien (12\%; Tabel 3).

Evaluasi ulang nyeri luka bakar setelah dilakukan tindak lanjut dari pengkajian nyeri yang dilakukan sesuai SPO pada nyeri berat sebanyak 7 pasien (88\%). Evaluasi ulang untuk nyeri sedang yang dilakukan sesuai SPO ditemukan pada 44 pasien (92\%). Untuk evaluasi ulang nyeri ringan yang dilakukan sesuai SPO ditemukan pada 42 pasien $(98 \%$; Tabel 4).

\section{Pembahasan}

Persepsi nyeri yang dialami pasien bersifat subjektif sehingga tidak ada dua orang yang mengalami rasa nyeri dengan respons dan perasaan yang sama. Beberapa faktor yang dapat memengaruhi persepsi nyeri pada luka bakar, yaitu usia, jenis kelamin, tingkat pendidikan, dan luas luka bakar. ${ }^{14}$

Pada penelitian ini didapatkan jumlah sampel sebanyak 99 pasien dengan usia rerata $43,70 \pm 14,62$ tahun. Penelitian ini mendapatkan usia terbanyak pasien luka bakar adalah pada rentang usia 41 sampai 60 tahun (48\%). Penelitian sebelumnya menemukan rentang usia 20 sampai 40 tahun merupakan usia pasien dengan luka bakar terbanyak $(61,1 \%)$. Hal ini menurut pendapat ahli terjadi karena luka bakar merupakan trauma yang sebagian besar disebabkan oleh

Tabel 4 Evaluasi Ulang Nyeri Luka Bakar

\begin{tabular}{lcc}
\hline \multicolumn{1}{c}{ Nyeri } & $\begin{array}{c}\text { Sesuai SPO } \\
\mathbf{n = 9 3}\end{array}$ & $\begin{array}{c}\text { Tidak Sesuai SPO } \\
\mathbf{n = 6}\end{array}$ \\
\hline Berat 1 jam & $7(88 \%)$ & $1(12 \%)$ \\
Sedang 2 jam & $44(92 \%)$ & $4(8 \%)$ \\
Ringan 8 jam & $42(98 \%)$ & $1(2 \%)$ \\
Total & $93(94 \%)$ & $6(6 \%)$ \\
\hline
\end{tabular}

Keterangan: data kategorik, data disajikan dengan jumlah atau frekuensi dan persentase 
kelalaian di rumah ataupun di tempat kerja dan dapat terjadi pada usia produktif yang pada usia tersebut fungsi dan peran sebagai pekerja sehingga memungkinkan kejadian trauma luka bakar banyak terjadi pada saat melakukan aktivitas dalam bekerja. Pada penelitian sebelumnya ini menyatakan pula tidak ada korelasi antara usia dan persepsi nyeri, namun didapatkan bahwa pasien yang lebih muda memiliki skor nyeri lebih tinggi daripada yang lebih tua. Pengaruh usia pada persepsi nyeri tidak diketahui secara luas. Orang tua berespons terhadap nyeri berbeda dengan orang yang lebih muda, beberapa faktor yang memengaruhi orang tua bahwa mereka berpendapat bahwa nyeri yang terjadi merupakan sesuatu yang harus diterima dan kebanyakan orang tua takut terhadap efek samping obat antinyeri berhubung dengan penyakit penyerta yang ada sehingga mereka tidak melaporkan derajat nyeri sesuai dari yang seharusnya dirasakan. ${ }^{15-17}$

Luas luka bakar terbanyak adalah luka bakar dengan luas luka bakar sebesar $\leq 10 \%$ total body surface area (47\%) dan kedua terbanyak adalah luka bakar dengan luas luka bakar 11-20\% total body surface area (30\%). Pengaruh luas luka bakar terhadap persepsi derajat nyeri tidak selalu berbanding lurus, hal ini ditentukan oleh faktor yang lain seperti kedalaman luka bakar. Pada penelitian ini didapatkan hasil yang tidak jauh berbeda dengan penelitian sebelumnya bahwa luas luka bakar yang terbanyak adalah luas luka bakar $<20 \%$ total body surface area. ${ }^{7}$

Data karakteristikjenis kelamin pasien yang didapat pada penelitian ini adalah pasien lakilaki sebanyak 69 pasien (70\%). Pada penelitian yang dilaksanakan sebelumnya didapatkan bahwa laki-laki yang terkena luka bakar lebih banyak dibanding dengan perempuan $(75,9 \%$ vs $24,1 \%$ ). Hal ini kemungkinan disebabkan oleh lingkungan kerja laki-laki memiliki risiko terkena luka bakar lebih besar dibanding dengan perempuan. Namun, secara statistik sesudah dilakukan Uji Fisher Exact tidak terdapat hubungan yang bermakna antara jenis kelamin dan terjadinya luka bakar. Perbedaan jenis kelamin telah diidentifikasi dalam hal persepsi nyeri karena laki-laki memiliki sensitivitas yang lebih rendah dibanding dengan perempuan atau kurang merasakan nyeri. Laki-laki kurang mengekspresikan nyeri yang dirasakan bila dibanding dengan perempuan. Hasil penelitian yang sebelumnya mengenai hubungan kebutuhan morfin pascabedah dengan total responden sebesar 2.298 pasien menunjukkan bahwa wanita kurang mengonsumsi morfin melalui patient controlled analgesia (PCA) daripada laki-laki pada nyeri pascabedah. 7,17

Latar belakang pendidikan terakhir terbanyak adalah Sekolah Lanjutan Tingkat Atas (SLTA) sebesar 75\%. Pengaruh tingkat pendidikan itu terhadap persepsi nyeri berhubungan dengan komunikasi yang disampaikan oleh pasien tentang sesuatu yang dirasakannya. Pengkajian nyeri merupakan kajian yang bersifat subjektif dan komunikatif yang berasal dari pasien. Tingkat pendidikan merupakan salah satu faktor yang menentukan terhadap perubahan perilaku, bahwa semakin tinggi tingkat pendidikan seseorang semakin banyak proses dan pengalaman belajar terhadap lingkungan yang ada di sekitarnya, termasuk pula nyeri yang dirasakan. Namun, penelitian yang terkait antara pengaruh tingkat pendidikan dan nyeri menunjukkan tidak terdapat hubungan bermakna., ${ }^{77}$

Pengkajian nyeri luka bakar yang sesuai dengan SPO sebanyak 99 pasien (100\%). Hasil ini didapatkan karena RSUP Dr. Hasan Sadikin sudah menerapkan lembar pengkajian nyeri yang terintegrasi di dalam rekam medis pasien baru sehingga petugas medis (baik dokter maupun perawat) dapat mudah melakukan pengkajian. Dalam suatu penelitian ditemukan bahwa pengkajian nyeri yang segera (early assessment) dan dilakukan secara tepat dapat meningkatkan keberhasilan manajemen nyeri akut dan juga meningkatkan keberhasilan pengobatan luka bakar itu sendiri sehubungan dengan penurunan reaksi inflamasi yang terjadi pada luka bakar. ${ }^{14}$ Faktor psikologis pasien dapat juga dipengaruhi pengkajian nyeri yang cepat. Pengkajian nyeri yang cepat dan pengobatan yang tepat sesuai dengan skala nyeri sangat penting karena dapat mengatasi 
pengalaman buruk pasien akan nyeri luka bakar sehingga dampak psikologis pasien dengan luka bakar tersebut tidak terganggu dan tidak terjadi nyeri kronik akibat nyeri akut yang tidak diatasi dengan baik. Pengkajian nyeri yang tidak benar akan berpengaruh terhadap ketepatan pemberian terapi sehingga kemungkinan terjadi komplikasi lebih besar, salah satu contoh adalah nyeri kronik yang sulit untuk diobati. ${ }^{18,19}$

Tindak lanjut hasil pengkajian nyeri luka bakar yang sesuai SPO didapatkan pada 71 pasien $(72 \%)$. Tindak lanjut pengkajian nyeri dilaksanakan untuk menilai apakah pengobatan nyeri sudah sesuai dengan skala nyeri sebagaimana telah diatur dalam SPO manajemen nyeri. Hasil ini menjelaskan bahwa analgesik yang diberikan tidak cukup baik dan terdapat $28 \%$ pemberian analgesik tidak sesuai dengan skala nyeri yang terjadi (atau tidak sesuai dengan SPO manajemen nyeri). Hal ini dapat terjadi karena beberapa faktor seperti obat yang tidak ada, persediaan obat yang habis, ataupun pengetahuan tentang manajemen nyeri yang baik masih kurang. Dari segi SPO, hal ini dapat terjadi karena sosialisasi SPO manajemen nyeri itu sendiri kurang. Dari segi dokter maupun perawat, hal ini mungkin dapat terjadi karena tidak tersampainya instruksi yang diberikan ataupun instruksi sudah diberikan, namun tidak dikerjakan sesuai dengan SPO manajemen nyeri. Hal tersebut membutuhkan penelitian lebih lanjut untuk menentukan penyebabnya.

Penggunaan analgesik yang diberikan pada pasien luka bakar pada skala nyeri ringan, sedang, dan berat dikelompokkan berdasar obat yang diberikan, seperti parasetamol, NSAID, opioid lemah, opioid kuat, dan kombinasi NSAID ditambah opioid lemah atau opioid kuat. Sesuai dengan buku panduan nyeri RSUP Dr. Hasan Sadikin Bandung, terapi farmakologi yang rasional untuk nyeri ringan adalah parasetamol atau NSAID, terapi nyeri sedang dengan kombinasi opioid lemah dan parasetamol/NSAID, sedangkan terapi nyeri berat dengan kombinasi opioid kuat dan parasetamol/NSAID. Pada penelitian ini didapatkan hasil pemberian terapi yang tidak sesuai SOP pada nyeri sedang (8\%) dan nyeri berat $(12 \%)$. Pemberian analgesik yang tidak sesuai dengan tingkat nyeri akan menimbulkan efek yang tidak diinginkan, seperti pemberian opioid dapat menimbulkan efek samping depresi pernapasan, mual muntah, penurunan tingkat kesadaran, serta dapat menurunkan respons simpatis pasien. Sebaliknya, pemberian obat analgesik yang kurang dari tingkat nyeri baik dosis maupun jenis analgesik dapat menyebabkan beberapa akibat, yaitu nyeri yang tidak hilang atau berkurang, meningkatkan risiko nyeri kronik, meningkatkan respons inflamasi tambahan, dan selanjutnya akan meningkatkan kejadian morbiditas, lama penyembuhan luka juga meningkat, meningkatkan waktu perawatan di rumah sakit yang akan berakibat lanjut risiko infeksi nasokomial meningkat., ${ }^{3,4}$

Evaluasi ulang pada nyeri perlu dilakukan sesuai dengan pedoman yang sudah dibuat dan pada pengalaman penelitian sebelumnya menyatakan bahwa evaluasi ulang nyeri pada terapi nyeri dapat meningkatkan kualitas manajemen nyeri serta menurunkan respons inflamasi yang dapat merusak seluruh organ tubuh. ${ }^{20}$ Tujuan evaluasi ulang nyeri adalah sebagai acuan bagi dokter dan perawat dalam penerapan langkah-langkah selanjutnya untuk mengidentifikasi rasa nyeri yang dirasakan pasien setelah diberikan terapi. ${ }^{13}$

Pada pedoman yang sudah dibuat oleh tim manajemen nyeri RSUP Dr. Hasan Sadikin, evaluasi ulang nyeri dilakukan dengan interval 8 jam untuk nyeri ringan dan tidak nyeri, 2 jam untuk nyeri sedang, serta setiap jam untuk nyeri berat. Nyeri dapat dinilai segera setelah diberikan intervensi analgesik, seperti contoh pemberian obat opioid parenteral dapat dinilai ulang nyeri segera setelah diberikan 15 sampai 30 menit dan 1 jam bila diberikan secara oral. Penilaian ulang segera dan tepat merupakan strategi yang efektif dalam penanganan nyeri akut, termasuk di dalamnya adalah luka bakar sehingga keberhasilan manajemen pengobatan luka bakar dapat tercapai. Evaluasi ulang yang tidak sesuai dengan pedoman akan menyebabkan nyeri yang tidak teratasi dan dapat menimbulkan nyeri kronik, yang dapat 
memperlama perawatan di rumah sakit. ${ }^{13,19}$

Pada penelitian ini terdapat $12 \%$ nyeri berat yang dilakukan evaluasi tidak sesuai dengan SPO. Hal ini mungkin disebabkan oleh keterbatasan jumlah tenaga kesehatan dan pengetahuannya terhadap SPO yang sudah dibuat. Pada SPO dinyatakan bahwa pada nyeri berat harus dilakukan evaluasi ulang setelah 1 jam diberikan analgesik. Terutama untuk nyeri berat karena nyeri berat yang tidak dilakukan evaluasi sesuai dengan SPO dapat mengakibatkan terapi yang salah dan paling besar kemungkinan timbul risiko nyeri kronik. Selain itu, komplikasi lain yang dapat timbul adalah meningkatkan respons inflamasi tambahan yang selanjutnya akan meningkatkan morbiditas yang menurunkan proses penyembuhan luka, meningkatkan waktu perawatan di rumah sakit yang akan berakibat lanjut meningkatkan risiko infeksi nasokomial. ${ }^{3,4}$

\section{Simpulan}

Pengkajian nyeri pada seluruh pasien luka bakar di RSUP Dr. Hasan Sadikin tahun 2018 sudah sesuai dengan SPO manajemen nyeri. Tindak lanjut hasil pengkajian nyeri luka bakar dan evaluasi ulang yang dilakukan belum sesuai dengan SPO manajemen nyeri.

\section{Daftar Pustaka}

1. Braveman FR. A WHO plan for burn prevention and care. 2018 [diunduh 1 Mei 2019]. Tersedia dari: https://www.who. int/news-room/fact-sheets/detail /burns.

2. Smolle C, Daniel JC, Forbes AA. Recent trends in burn epidemiology worldwide: a systematic review. PMC. 2017;43(2):24957.

3. Beel A, Grantham D. Module 2: pain assessment and management. 2010. [diunduh 14 Juli 2018]. Tersedia dari: http://www.palliative. info/mpcna/ module2.pdf.

4. Guttormsen AB, Berger MM, Sjoberg F, Heisterkamp H. Burn injury clinical problems. An ESICM. 2012. [diunduh 14 Juli 2018]. Tersedia dari: http:// pact.esicm.org/media/Burns_Injury_3_ Dec_2012_final.pdf.

5. Prabandari DA, Indriasari, Maskoen TT. Efektivitas analgesik 24 jam pascaoperasi elektif di RSUP Dr. Hasan Sadikin Bandung tahun 2017. JAP. 2018;6(2):98-104.

6. Winanda RA, Kusumadewi I, Wardhana A. The association between psychopathology and quality of life in burn patients at Dr. Cipto Mangunkusumo Hospital Jakarta. J Plastik Rekonstruksi. 2017; 2:105-12.

7. Febrianto $\mathrm{R}$, Farhanah N, Sari EP. Hubungan luka bakar derajat sedang dan berat menurut kategori american burn association dan faktor yang mempengaruhi kejadian sepsis di RSUP Dr. Kariadi. J Kedokteran Diponegoro. 2016;5(4):1526-34.

8. Longnecker DE, Orkin FK. Anesthesia risk. Dalam: Longnecker DE, Mackey SC, Newman MF, Sandberg WS, Zapol WM, penyunting. Anesthesiology. Edisi ke3. New York: McGraw Hill; 2010. hlm. 291-306.

9. Bittner EA, Martyn JA. Evaluation and anesthetic management of the burn injured patient. Dalam: Longnecker DE, Mackey SC, Newman MF, Sandberg WS, Zapol WM, penyunting. Anesthesiology. Edisi ke-3. New York: McGraw Hill; 2010. hlm. 1251-69.

10. Figy S, McIntyre JK. Burn management. Dalam: Irwin RS, Lilly CM, Mayo PH, Rippe JM, penyunting. Irwin and Rippe's intensive care medicine. Edisi ke-8. Philadelpia: Lippincott Williams \& Wilkins; 2011. hlm 1728-32.

11. Nair S, Neil MJE. Paediatric pain: physiology, assessment and pharmacology. ATOTW. 2013;289:1-10.

12. Cohen LL, Lemanek K, Blount RL, Dahlquist LM, Lim CS, Palermo TM, dkk. Evidencebased assessment of pediatric pain. J Pediatr Psychol. 2008;33(9):939-55.

13. Panduan Manajemen Nyeri. Bandung: RSUP Dr. Hasan Sadikin; 2015 [diunduh 14 juli 2018]. Tersedia dari: http://arsip.rshs. 
orid.

14. Abraham J. Burn trauma: an emerging model for acute pain. J Clin Studies. 2016;7(6):34-6.

15. Purwaningsih LA, Rosa EM. Respons adaptasi fisiologis dan psikologis pasien luka bakar yang diberikan kombinasi alternative moisture balance dressing dan seft terapi di RSUP Dr. Sardjito Yogyakarta. J Universitas Muhammadiyah. 2014:41-9.

16. Gowri S, Vijaya N, Powar R. Original research paper epidemiology and outcome of burn injuries. J Indian Acad Forensic Med. 2012;34(4):312-4.

17. Maske AN, Deshmukh SN. Clinicoepidemiology study of burns: our experiences with 500 patients. Int Surg J. 2016;3(3):1234-9.

18. Hale A, O'Donovan R, Diskin S, McEvoy S, Keohane C. Physiotherapy in burns, plastics and reconstructive surgery. Impairment and Disability Course University of Limerick. Irlandia: The Educational Company of Ireland; 2013. hlm. 2-26.

19. Grantham D, Brown S. Pain assessment and management, clinical practice guidelines. Montreal: Winnipeg Regional Health Authority; 2012.

20. Griggs C, Goverman J, Bittner E, Levi B. Sedation and pain management in burn patients. Clin Plast Surg. 2017;44(3):535-40. 